This is a preprint of an article accepted for publication in the Journal of Contemporary China, Vol. 23, No. 86, March 2014. JCC is is available online at:

http://www.tandfonline.com/toc/cjcc20/current;

8,732 words including notes and tables, 30.7.12

\title{
Profiling the Victims: Public Awareness of Pollution-related Harm in China
}

\author{
Dr Neil Munro \\ School of Social and Political Sciences, \\ University of Glasgow, GLASGOW G12 8RT, \\ Scotland, UK. \\ Email: Neil.Munro@glasgow.ac.uk. \\ Tel. +44-141-3307628
}

\begin{abstract}
This article aims to identify factors which influence public awareness of health or economic harm from pollution in China. Based on an analysis of the China General Social Survey (CGSS) carried out nationwide by Renmin University and HKUST in 2006, it focuses on awareness of pollutionrelated harm or self-identification as a pollution victim. The analysis tests three groups of hypotheses about how self-identified victims differ from others: first, in terms of the environmental conditions they experience, such as the actual level of pollution and types of neighbourhoods they inhabit; second, in terms of resources including material and information resources, time, social capital and political experience; and third, in terms of political attitudes. The conclusion discusses implications for the politics of public participation in environmental governance in China.
\end{abstract}

Key words: environmental awareness, pollution victims, China 


\section{Introduction}

There have been a great many studies from a variety of disciplinary perspectives looking at issues of environmental justice in China, including some looking at the distribution of pollution, ${ }^{1}$ but relatively few that look at awareness of pollution as a problem ${ }^{2}$. The extant survey-based studies tend to show that awareness of different kinds of pollution is high ${ }^{3}$ but most of these are content with reporting distributions, without analysing the data in depth or offering any hypotheses to explain awareness ${ }^{4}$. There are few studies which problematize awareness of harm from pollution.

Awareness of harm is important from a theoretical perspective since the literature on dispute resolution describes the process of developing grievances in terms of a so-called "dispute pyramid" with three steps: naming, blaming and claiming ${ }^{5}$. The first step involves becoming aware of the seriousness of an injury, the second involves attributing it to the actions of someone else and the third step involves use of voice, addressed either at the person blamed or a third party. This description encourages us to examine awareness of and action against pollution as parts of a segmented process, in which the first step is self-identification as a pollution victim. Within the context of Chinese social science research, there have been a number of successful studies of the blaming and claiming part of this process ${ }^{6}$, but no one, to this author's knowledge, has yet looked

\footnotetext{
${ }^{1}$ Recent examples include E. D. Schoolman and C. B. Ma, "Migration, Class and Environmental Inequality: Exposure to Pollution in China's Jiangsu Province," Ecological Economics 75(2012), pp.140-51. L. Liu, "Environmental Poverty, a Decomposed Environmental Kuznets Curve, and Alternatives: Sustainability Lessons from China," Ecological Economics 73(2012), pp.86-92; P. L. Xue and W. H. Zeng, "Trends of Environmental Accidents and Impact Factors in China," Frontiers of Environmental Science \& Engineering in China 5, no. 2 (2011), pp.266-76; C. B. Ma, "Who Bears the Environmental Burden in China-an Analysis of the Distribution of Industrial Pollution Sources?," Ecological Economics 69, no. 9 (2010), pp.1869-76.

${ }^{2}$ One survey-based study looked at the relationship between pollution and wellbeing - see Russell Smyth et al., "A Study of the Impact of Environmental Surroundings on Personal Well-Being in Urban China Using a Multi-Item WellBeing Indicator," Population \& Environment 32, no. 4 (2011), pp.353-75. For a variety of social scientific perspectives on the environment and health, see the special edition of Journal of Contemporary China, vol. 19, no.63 (2010).

${ }^{3}$ For example, across eight different types of pollution, a median of 73 per cent agreed or strongly agreed that pollution was a serious problem in Guangzhou according to a survey with 916 respondents carried out in five urban districts in October 1996. See Carlos Wing Hung Lo and Sai Wing Leung, "Environmental Agency and Public Opinion in Guangzhou: The Limits of a Popular Approach to Environmental Governance," China Quarterly 163(2000), p.688. For similar results see also Koon-Kwai Wong, "Greening of the Chinese Mind: Environmentalism with Chinese Characteristics," Asia-Pacific Review 12, no. 2 (2005), pp.39-57; Paul G. Harris, "Environmental Perspectives and Behavior in China," Environment and Behavior 38, no. 1 (2006), pp.5-21..

${ }^{4}$ A five-city survey in Liaoning with 5,996 respondents attempted a corporatist approach to sample design, producing six sub-samples representing residents, policy-makers, teachers, students, staff of industrial enterprises, and farmers. Whilst confirming that concern about pollution is widespread, it found only one important difference between the groups in levels of concern - students were more concerned about global climate change compared to the other groups. See Peijun Li, Frank Stagnitti, and Zongqiang Gong et al., "Environmental Quality: Issues and Causes of Deterioration - a Survey on Environmental Awareness among the Public in Liaoning Province, China," International Journal of Sustainable Development \& World Ecology 16, no. 3 (2009)., p.146.

${ }^{5}$ William L. F. Felstiner, Richard L. Abel, and Austin Sarat, "The Emergence and Transformation of Disputes: Naming, Blaming, Claiming," Law \& Society Review 15, no. 3/4 (1981), pp.631-54

${ }^{6}$ Kathinka Fürst, "Access to Justice in Environmental Disputes: Opportunities and Obstacles for Chinese Pollution Victims," (University Of Oslo, 2008); Rachel E. Stern, "From Dispute to Decision: Suing Polluters in China," China Quarterly 206(2011), pp.294-312; Benjamin van Rooij, "The People Vs. Pollution: Understanding Citizen Action against Pollution in China," Journal of Contemporary China 19, no. 63 (2010), pp.55-77
} 
at the naming part, that is the process by which people become aware of pollution as a problem from an egocentric viewpoint. There is a need to understand this process in order to judge the public's capacity to become a significant actor in pollution control.

This article offers a study of the characteristics of self-identified pollution victims based on a nationally representative sample. The section below describes the data and research design and explains the measure of self-identification. Section three develops hypotheses to explain the distribution. Section four presents bivariate analysis and a multi-level logistic regression to test the hypotheses. The conclusion reviews some of the limitations of the study and the data on which it is based, and speculates about the implications of the analysis for understanding the politics of public participation in environmental governance in China.

\section{Data and Measures}

This study is based on analysis of data from the China General Social Survey (CGSS), carried out nationwide from September to November $2006^{7}$ by Renmin University and the Hong Kong University of Science and Technology ${ }^{8}$. The survey took place in 969 tertiary sampling units including 559 urban neighbourhoods and 410 administrative villages using stratified proportionate to population probability sampling across 28 provinces of mainland China. The tertiary sampling units were randomly selected from settlement lists compiled for the 2000 census. Where there were significant changes in neighbourhood or village boundaries, population movements or changes in administrative status between the census and the date of survey, the area sampled was adjusted to reflect as closely as possible the situation as of the 2000 census. Within each settlement, individual households were selected by proceeding on a random route, with the aim of achieving a quota of ten households per sampling unit. The result was a sample with a total of 10,151 respondents, one of the largest publicly available opinion surveys in China. Ten per cent of the sample classified themselves as migrant workers or migrant business people (wailai gong, wailai jingshangren).

CGSS asked respondents whether they had experienced any harm to their health or livelihood from pollution over the past year (Table 1). Just over six per cent of respondents believed they or their family members had suffered harm. It is important to emphasize that the measure is a subjective opinion. When we compare it to official statistics which for example report that in 2006, $9.1 \%$ of 559 cities surveyed failed to meet even the lowest Grade III air quality, and $28 \%$ of 745

\footnotetext{
${ }^{7}$ CGSS has also made available the 2003, 2005 and 2008 surveys, but these do not include the dependent variable analysed here.

${ }^{8}$ Lulu Li and Yanjie Bian, "China General Social Survey 2006," (Beijing: National Survey Research Centre at Renmin University of China, 2006). CGSS is sponsored by the China Social Science Foundation. The author appreciates the assistance in providing the data by the institutes and individuals aforementioned, but all views expressed here are the author's own.
} 
river sections failed to meet even the lowest Grade $V$ water quality ${ }^{9}$, it is clear that the number of people who actually suffer harm from pollution could be much greater than just six per cent. Some of these may have not noticed the harm--for example health damage which has not yet revealed symptoms or economic costs which are borne above the household level. Some may have noticed harm but not attributed it to pollution. There may also be "false claimants" to victimhood, whose subjective response to pollution is out of proportion to the actual harm they suffered.

[Table 1 about here]

\section{Hypotheses}

Studies of environmental management in China acknowledge that there have been some spectacular improvements in urban amenity and significant attempts at mitigating the level of pollution which has resulted from China's transformation into a major industrial power, but many are also critical of the way in environmental risks have been unevenly distributed. Tu and Shi ${ }^{10}$, for example, noted that Shanghai's approach to sewerage management during the 1990s and early 2000s involved displacing the problem by diverting it into the Yangtze Estuary and East China Sea, raising significant issues of geographic and intergenerational inequity. Dasgupta and Wheeler ${ }^{11}$ found using provincial-level data over 1987 to 1993 that the number of environmental complaints per 10,000 inhabitants was a function of the density of airborne dust emissions, but not sulphur dioxide emissions nor water born chemical oxygen demand, and reasoned that this was because dust is visible in a way that the other pollution is not. Brettell ${ }^{12}$ used separate data for water and air pollution complaints over the period 1990 to 2004 to show that total industrial wastewater effluent and sulphur dioxide emissions partially explain an increase in the respective types of complaints. If complaints have an objective basis, then it is reasonable to hypothesise that self-identified pollution victims live in more polluted environments than others (H1a). The same studies also showed associations, controlling for pollution indicators, between environmental complaints at the aggregate level and the wealth of a city or region, whether measured as real consumption per capita ${ }^{13}$ or GDP per capita ${ }^{14}$, as well as between complaints and education as

\footnotetext{
${ }^{9}$ MEP, "State of the Environment 2006," (Beijing: Ministry of Environmental Protection, 2006).

${ }^{10}$ W. Tu and C. Shi, "Urban Environmental Management in Shanghai: Achievements, Problems, and Prospects," Environmental Management 37, no. 3 (2006), p.315. These authors see intergenerational, geographic, procedural and interspecies equity as the key to sustainable development, and argue that the general public is the "fundamental force in driving the course of sustainable urban development" (p.319).

${ }^{11} \mathrm{~S}$. Dasgupta and D. Wheeler, "Citizen Complaints as Environmental Indicators: Evidence from China," World Bank Policy Research Working Papers, no. 1704 (1997), p.13, 21

${ }^{12}$ Anna Brettell, "Channelling Dissent: The Institutionalization of Environmental Complaint Resolution," in China's Embedded Activism: Opportunities and Constraints of a Social Movement, ed. Peter Ho and Richard L. Edmonds (London and New York: Routledge, 2008), p.122

${ }_{3}^{3}$ Dasgupta and Wheeler, "Citizen Complaints as Environmental Indicators: Evidence from China", p.21

${ }^{14}$ Brettell, "Channelling Dissent: The Institutionalization of Environmental Complaint Resolution", p.122. We should be cautious about how this relationship plays out at the level of particular communities. EPB officials informed Zhang that
} 
measured by provincial literacy rates. Dasgupta and Wheeler interpret these data as indicating "elasticity of demand for environmental quality." 15 . Since income and education vary more between individuals and households than between regions, using individual-level survey data, we can improve upon the accuracy of these results. Of more interest than simply replicating the aggregate-level studies is to consider whether there are other "ecological" effects on selfidentification as a pollution victim which are not captured by official pollution statistics. In this study, we consider three such effects. One is the general effect of level of development, as measured by GDP per capita, which we hypothesise may decrease the number of self-identified pollution victims owing to better environmental management $(H 1 b)$. The second is the effect of the population size of nearby cities, which we hypothesise may increase the number of pollution victims, since larger populations may generate other forms of pollution which are not captured by official statistics (H1c). The third is the type of area the respondent inhabits. Conventionally, areas are often divided between urban and rural administrative jurisdictions, but CGSS offers a more detailed variable -- type of neighbourhood (shequ leixing). We hypothesise that this variable matters because cities and counties - the typical units of aggregate-level analysis -- are geographic spaces which are structured internally. Our general expectation is that people in less desirable neighbourhood types are more likely to self-identify as pollution victims $(H 1 d)$.

The concept of elasticity of demand raises the question of how subjective factors may influence self-identification as a pollution victim. Both Liberal and Marxist traditions emphasize the role of scarcity in driving forward economic and social development, and in the contemporary discourse of sustainable development, this includes the scarcity of environmental amenity ${ }^{16}$. Hirschman ${ }^{17}$ observed in mid-twentieth century America that complaints about the impact of environmental changes on quality of life were most forthcoming amongst those who already enjoyed a high level of amenity. Johnson's ${ }^{18}$ case studies of NIMBY resistance to the construction of a paraxylene plants in Xiamen and a waste incinerator in Beijing, seemed to involve people from all walks of life — not just the relatively well off. In other words, concerns about impacts on health and property prices were widely shared. However, in Xiamen, the outcomes of the protests included, after a two-day public hearing to deliberate on a strategic environmental impact assessment, a decision to relocate the plant to the nearby city of Zhangzhou, where presumably there was less likelihood

in the context of the green bounty programme in Fuyang City, many of the informants were farmers, and very few were whistle blowers from within enterprises. See Xuehua Zhang, "Green Bounty Hunters: Engaging Chinese Citizens in Local Environmental Enforcement," China Environment Series, no. 11 (2011), p.147.

${ }_{15}$ Dasgupta and Wheeler, "Citizen Complaints as Environmental Indicators: Evidence from China", p.11

${ }^{16}$ P. Tijmes and R. Luijf, "The Sustainability of Our Common Future - an Inquiry into the Foundations of an Ideology," Technology in Society 17, no. 3 (1995), p.335

${ }^{17}$ Albert O. Hirschman, Exit, Voice and Loyalty: Responses to Decline in Firms, Organizations and States (Cambridge, MA: Harvard University Press, 1970), p.53

18 T. Johnson, "Environmentalism and Nimbyism in China: Promoting a Rules-Based Approach to Public

Participation," Environmental Politics 19, no. 3 (2010), pp.440ff 
of protes ${ }^{19}$. In Beijing, a mass petition facilitated the suspension of the waste incineration project, centred on the Liulitun area of Haidian district, which is home to China's top universities. The general notion we are interested in testing is that people with greater resources may have higher levels of awareness of the harm caused by pollution because they have higher expectations of environmental amenity. We can make this into a set of falsifiable hypotheses by considering the relationship between awareness of harm and different types of resources. These include not only material resources, but also such factors as time, social capital including both horizontal and vertical ties, informational resources such as knowledge and cognitive ability, and political experiences which "raise consciousness" 20 .

Alford et al. ${ }^{21}$ found in a sample consisting mainly of Anhui farmers a positive correlation between environmental awareness and household wealth. If there is a class dimension to selfidentification as a pollution victim, we should expect to find income and/or assets matter even when other relevant variables are controlled (H2a). People with time on their hands may be more likely to worry about the environment, and so develop a sense of anxiety about pollution. A study of public participation in public policy-making in Chengdu found that people in their twenties and the over-sixties were more likely to participate in public policy-making than people in their thirties, forties and fifties, married people were less likely to participate than unmarried people, and married people with children were least likely of all to participate ${ }^{22}$. If having time on your hands matters, we would expect that young people and those who are retired are more likely to selfidentify as pollutions victims (H2b).

Similarly, people who have a larger stock of social capital may develop a shared sense of grievance through social interaction. Again, awareness of harm and action against pollution are not the same thing, and most prior studies have focussed on the latter. $\mathrm{Zhu}$ and $\mathrm{Ho}^{23}$ noted that the preservation of neighbourhood ties when residents of an old part of Shanghai moved en masse into new apartments in the "Green Garden" neighbourhood helped initiate and sustain an effective campaign against later attempts to build on park land near their new apartments. Jennings ${ }^{24}$ found that having a second occupation was a positive predictor of engaging in

\footnotetext{
${ }^{19}$ Ibid., p.441. In 2010, average annual wages for urban employees in Zhangzhou were 26 per cent lower than in Xiamen. See National \& Fujian Province Bureaux of Statistics, Fujian Tongji Nianjian 2011 [Fujian Statistical Yearbook 2011). (Beijing: China Statistics Press, 2011), p.565

${ }^{20}$ van Rooij, "The People Vs. Pollution: Understanding Citizen Action against Pollution in China.", p.63f

${ }^{21}$ William P. Alford et al., "The Human Dimensions of Pollution Policy Implementation: Air Quality in Rural China,"

Journal of Contemporary China 11, no. 32 (2002), p.505

${ }_{22}$ Chunmei Li, "Chengzhen Jumin Gongzhong Canyu Yu Taidu Shizheng Yanjiu--Yi Chengdu Shi Wei Li [Empirical Research on Urban Residents Public Participation and Attitudes--Chengdu as an Example]," Journal of China National School of Administration 5(2006), p.69. Unfortunately, this article does not give full details of the survey.

${ }^{23}$ Jiangang Zhu and Peter Ho, "Not against the State, Just Protecting Residents' Interests: An Urban Movement in a Shanghai Neighbourhood," in China's Embedded Activism: Opportunities and Constraints of a Social Movement, ed. Peter Ho and Richard L. Edmonds (London and New York: Routledge, 2008), p.167

${ }^{24}$ M. Kent Jennings, "Political Participation in the Chinese Countryside," American Political Science Review 91, no. 2 (1997), p.369
} 
demanding forms of political participation. We can test the notion that people with a larger stock of social capital are more likely to self-identify as pollution victims (H2c).

Political experience may serve to "raise consciousness" about environmental issues. In the Green Garden dispute in Shanghai, residents specifically sought out an individual with experience in dealing with neighbourhood conflicts to be their spokesman ${ }^{25}$. Unusual political skill was a requirement for the job, and the activities organized by this person subsequently "raised consciousness" and the will to fight of many others in the neighbourhood. A striking feature of the case-study literature is how local attempts to influence policy implementation, especially in rural areas can escalate, involving larger numbers of people in contentious discussions and in collective action, sometimes inside the boundaries of legality and sometimes transgressing them ${ }^{26}$. As O'Brien and Li observe, "Direct tactics can help a group of activists to expand their base by creating solidarity, forging a collective identity, and strengthening trust." ${ }^{27}$ We can test the hypothesis that political experience encourages people to self-identify as pollution victims (H2d).

Finally, we would expect information resources, including knowledge and cognitive ability, to increase awareness of environmental risks. Using individual-level data from their survey in rural Anhui, Alford et al. ${ }^{28}$ found that education was a significant positive influence on environmental awareness. Dasgupta and Wheeler ${ }^{29}$ found that the provincial literacy rate was a significant influence on environmental complaints. Alongside education, we should consider the effects of media exposure. In Fuyang city, Zhang ${ }^{30}$ reports, polluting enterprises were even more nervous about the effects of hostile media reports than about EPB fines. We should bear in mind that not all education is formal or takes the form of consumption of media. Jing ${ }^{31}$ documents how Dachuan village underwent a "cognitive revolution" about pollution after watching domesticated animals go blind, having the problem of stillbirths highlighted by population policies and health worker visits, and seeing fish ponds poisoned. Nevertheless, this kind of intensive, direct experience of pollution is probably unusual. Our general expectation is that those who have more education and higher media exposure are more likely to self-identify as pollution victims (H2e).

It is widely recognized in public opinion research that people make use of cognitive shortcuts to form opinions about unfamiliar issues quickly without necessarily making an effort to acquire

\footnotetext{
${ }^{25}$ Zhu and Ho, "Not against the State, Just Protecting Residents' Interests: An Urban Movement in a Shanghai Neighbourhood", p.156

${ }^{26}$ Kevin J. O'Brien and Lianjiang Li, Rightful Resistance in Rural China (Cambridge: Cambridge University Press, 2006); Jun Jing, "Environmental Protests in Rural China," in Chinese Society : Change, Conflict and Resistance ed. Elizabeth J. Perry and Mark Selden (London: RoutledgeCurzon, 2010); Johnson, "Environmentalism and Nimbyism in China: Promoting a Rules-Based Approach to Public Participation."

${ }^{27}$ O'Brien and Li, Rightful Resistance in Rural China, p.85

${ }^{28}$ Alford et al., "The Human Dimensions of Pollution Policy Implementation: Air Quality in Rural China", p.505

${ }^{29}$ Dasgupta and Wheeler, "Citizen Complaints as Environmental Indicators: Evidence from China", p.21

${ }^{30}$ Zhang, "Green Bounty Hunters: Engaging Chinese Citizens in Local Environmental Enforcement", p.150

31 Jing, "Environmental Protests in Rural China", p.199ff
} 
information which would allow them to base their opinion on evidence ${ }^{32}$. This kind of "prejudice" may lead to the association of particular political attitudes with self-identification as a pollution victim. When Fuyang city was considering introducing a green bounty programme, officials held a debate in which concern for the environment was pitted against the "growth first" mentality and some officials' fear of upsetting local enterprises ${ }^{33}$. We can hypothesise that general concern with green issues or with the environment makes people more sensitive to environmental risk and more likely to identify as pollution victims (H3a).

Inglehart's attempt to theorize patterns of value change posits the spread of "post-modern" values $^{34}$, referring to support for equality and greater tolerance of diversity. Wang Zhengxu deployed an analysis of data from seven countries in the Asia Barometer survey of 2006 to argue first, that post-modern values tend to be more widespread in more economically developed Confucian societies like Japan and Hong Kong, and less widespread in less developed Confucian societies like China and Vietnam; and second, post-modern values in Confucian societies generally encourage people to be more active politically, more assertive of individual and political rights, more supportive of democracy and, notably, more supportive of greater government attention to environmental policy ${ }^{35}$. Whilst the data analysed in this study do not allow a replication of the post-modern values measures used by Wang, we can test the general notion that those who are supportive of social and political equality are "sensitized" to environmental issues and hence more likely to self-identify as pollution victims (H3b).

We do not need to accept the Inglehart theory of post-modern value change in order to see a connection between concerns about equality and the environment. Jing's ${ }^{36}$ case study of Gaoyang village illustrates how distributional and political issues can become tied up with environmental conflict. There people lost their land as a result of the Three Gorges dam project and were inadequately compensated through the allocation of terraces which were not fit for farming. The environmental issue (the Three Gorges dam) was effectively obscured by the issue over land, questions about the legitimacy of local authorities accused of misusing land reclamation funds, and the ideological imperative not to oppose a major national project. The direct experience of unfair treatment may create a generalized sense of grievance which is another possible source of self-identification as a pollution victim (H3c).

\footnotetext{
32 John Zaller, The Nature and Origins of Mass Opinion (Cambridge: Cambridge University Press, 1992).

${ }^{33}$ Zhang, "Green Bounty Hunters: Engaging Chinese Citizens in Local Environmental Enforcement", p.148

${ }^{34}$ Ronald Inglehart, Culture Shift in Advanced Industrial Society (Princeton and Oxford: Princeton University Press, 1990); - Modernization and Postmodernization Cultural, Economic, and Political Change in 43 Societies (Princeton: Princeton University Press, 1997).. Inglehart has explicitly linked his theory to support for environmental protection. See _ _ "Public Support for Environmental Protection: Objective Problems and Subjective Values in 43 Societies," PS: Political Science and Politics 28, no. 1 (1995), pp.57-72

${ }^{35}$ Zhengxu Wang, "Postmodern Values in Seven Confucian Societies: Political Consequences of Changing World Views," Japanese Journal of Political Science 8, no. 3 (2007), p.348, p.355f.

36 Jing, "Environmental Protests in Rural China.", p.201ff
} 
Studies in a wide variety of developed and transitional countries suggest that critical citizens impose on governments higher standards of performance, which make it harder for them to earn popular trust ${ }^{37}$. In South Korea, for example, the factors which influence trust in government include government performance in dealing with environmental problems ${ }^{38}$ as well as living up to democratic ideals ${ }^{39}$. In China, survey-based studies have shown that, against the background of a generally high level of political trust, citizens with higher education tend to be more critical and those with more intense media exposure less critical of government ${ }^{40}$. Some researchers argue that social welfare and the supply of public goods are coming to replace economic development as important sources of political trust ${ }^{41}$. It is not unknown for local governments to conceal information about major pollution incidents in order to avoid public criticism ${ }^{42}$. To the extent that government media controls constitute an effective tool for manipulating public perceptions, and given that trust to some extent varies independently of education levels, we would expect that one of the consequences of a high level of trust in official information sources would be a lower propensity to self-identify as a pollution victim $(\mathrm{H} 3 \mathrm{~d})$.

\section{Explaining Self-Identification as a Pollution Victim}

Multinomial logistic regression is the appropriate tool for analysing the explanatory power of multiple independent variables for a binomial dependent variable. This technique estimates the association of the independent variables with the ratio of the odds that a respondent belongs to one category rather than another. The variant used here is a multi-level logistic regression analysis ${ }^{43}$ with the independent variables tested as a block and included in the model on the basis of likelihood ratio tests $(P<.15)$. The limited geographical scope of the official environmental data means that the analysis has to be based on a subsample of 751 sampling points, including 74 per cent of the cases in the full sample, clustered by the city holding jurisdiction including outlying rural

\footnotetext{
${ }^{37}$ Pippa Norris, "Conclusions: The Growth of Critical Citizens and Its Consequences," in Critical Citizens: Global Support for Democratic Governance, ed. Pippa Norris (Oxford and New York: Oxford University Press, 1999); P. Norris, Democratic Deficit: Critical Citizens Revisited, Democratic Deficit: Critical Citizens Revisited (Cambridge: Cambridge University Press, 2011).

${ }^{38}$ Soonhee Kim, "Public Trust in Government in Japan and South Korea: Does the Rise of Critical Citizens Matter?," Public Administration Review 70, no. 5 (2010), p.807

${ }^{39}$ Richard Rose, Doh C. Shin, and Neil Munro, "Tension between the Democratic Ideal and Reality: The Korean Example," in Critical Citizens: Global Support for Democratic Governance, ed. Pippa Norris (Oxford and New York: Oxford University Press, 1999).

${ }^{40}$ J.J. Kennedy, "Maintaining Popular Support for the Chinese Communist Party: The Influence of Education and the State-Controlled Media," Political Studies 57, no. 3 (2009), p.527

${ }^{41}$ T. G. Meng, "Government Governance and Political Trust in Transition China: An Empirical Analysis," Proceedings of 2009 International Conference on Public Administration (5th), Vol II (2009).

${ }^{42}$ For example, Harbin bore the brunt of a November 2005 benzene pollution disaster, which it took the authorities ten days to acknowledge publicly. See Robert Marquand, "Chinese Decry Toxic Cover-up," Christian Science Monitor 98, no. 2 (2005), pp.1-11.

${ }^{43}$ Using the Bernoulli model specification included in the HLM 6 programme. See Stephen W. Raudenbush and Anthony S. Bryk, Hierarchical Linear Models: Applications and Data Analysis Methods (Thousand Oaks: Sage Publications, 2002), chapter 10 for details of the procedure.
} 
areas $^{44}$. Areas under the jurisdiction of smaller cities and remote areas are excluded because no data is available on environmental conditions there ${ }^{45}$. The analysis also excludes one city where an exceptionally high level of awareness was found for the level of pollution ${ }^{46}$.

[Table 2 about here]

The model shows that in line with expectations about the effects of pollution on popular consciousness $(\mathrm{H} 1 \mathrm{a}, \mathrm{H} 1 \mathrm{c})$ the total volume of industrial waste water per capita is a significant predictor of self-identification as pollution victim $\left(T=2.64^{\star *}\right.$, Table 2$)$ as is the size of the population of the city with jurisdiction $\left(T=2.60^{*}\right)$, but contrary to our expectation that, controlling for the amount of pollution, level of development would reduce the number of self-identified victims $(\mathrm{H} 1 \mathrm{~b})$, GDP per capita is not significant. Chi-squared tests of alternative models confirm that, first, there is significant variation between cities, as shown by the fact that the variance of the intercept in the model with no city-level predictors is significantly different from zero (bottom panel, Table 2), and second, industrial waste water per capita (but not the other pollution indicators) and population size do significantly improve the model fit. The fact that city-level measures are statistically significant justifies the use of a multi-level model.

At the household level, the type of neighbourhood in which the respondent lives stands as a proxy for local environmental conditions which cannot be captured by statistics applying to a whole city. Consistent with our expectation that people in less desirable areas would be more likely victims $(\mathrm{H} 1 \mathrm{~d})$, every type of area apart from professional and high-end housing is more likely than the reference category of "ordinary commercial housing" to include residents who self-identify as pollution victims. People on rural plains $\left(T=4.68^{* * *}\right)$, in housing built for workers of industrial enterprises $\left(T=4.00^{\star * *}\right)$, and in mountainous areas $\left(T=3.20^{\star * *}\right)$ within a particular city's jurisdiction are amongst the most likely to be aware of environmental harm. We should bear in mind that the rural respondents included in the analysis are those living within the jurisdiction of a city, not all rural respondents.

Measures of resources such as income and the estimated value of housing, social capital, political experience, and information resources (knowledge and cognitive ability) were all tested

\footnotetext{
${ }^{44}$ For descriptive statistics of all the variables included in the model plus basic demographics and city-level pollution statistics see the Appendix. A longer list of all variables tested is available from the author.

${ }^{45}$ As a check on whether the reduced sample behaves differently to the full sample, a separate logistic regression model was developed using the full sample without the city-level indicators. The model confirms the findings reported here with minor variations: details available from the author. For a comparison of descriptive statistics of the full sample with the reduced sample, see Appendix.

${ }^{46}$ In the northern city of Harbin, $93 \%$ of respondents identified as pollution victims, even though the industrial waste water statistic of 3.4 tonnes per capita is on the low side. Since influential cases can bias statistical analysis, the decision was made to exclude Harbin (88 cases). The formal procedure used to identify Harbin as having exceptionally high self-identification as a victim for its actual level of pollution was the Box-Tidwell test, detailed in Scott W. Menard, Applied Logistic Regression Analysis (Thousand Oaks and London: Sage, 2002). pp.69-71.
} 
systematically for inclusion in the model. Most failed the tests, but in line with our hypothesis about political experience ( $\mathrm{H} 2 \mathrm{~d}$ ), having witnessed collective action is a highly significant positive influence $\left(T=7.15^{\star * \star}\right)$. One information measure $(\mathrm{H} 2 \mathrm{e})$, the number of books in the house when the respondent was 18 , was also significant $\left(T=2.75^{\star \star}\right)$, whereas the highest educational level reached was not.

In line with the green values hypothesis $(\mathrm{H} 3 \mathrm{a})$, the view that global environmental problems are serious is a significant positive influence $\left(T=5.86^{\star * *}\right)$ and the importance of the local environment as a spending priority is marginally significant $\left(T=2.25^{\star}\right)$. In terms of general concern with social and political equality ( $\mathrm{H} 3 \mathrm{~b})$, the view that the poor are poor because they lack education is significant $\left(T=3.08^{\star *}\right)$, and one other attitude-the view that rich-poor conflicts are serious-passes likelihood ratio tests for inclusion in the model but the coefficient is not significant at the 05 level. In line with the generalized grievance hypothesis $(\mathrm{H} 3 \mathrm{c})$, the experience of being unfairly treated in civil, political or economic disputes is highly significant $\left(T=8.18^{\star \star}\right)$. The measure of trust in government information, which we expected to reduce self-identification as a victim (H3d), passes likelihood ratio tests for inclusion in the model but the coefficient has a large standard error, and so the hypothesis is not confirmed.

We can quantify the impact of a standard deviation increase in the value of the independent variables and convert the resulting logged odds into probabilities to simulate substantive impacts (Figure 1). Such a procedure shows that environmental conditions at city level including aggregate pollution levels and population pressure have minimal impact on the likelihood of an individual self-identifying as a pollution victim. The reason for this is that the coefficients, although statistically significant, are small in magnitude. Environmental conditions at neighbourhood level have a much larger substantive impact. For example, living on a rural plain, which has the largest coefficient amongst neighbourhood types, more than doubles the likelihood of self-identifying as a victim of pollution from just fewer than two per cent to just under four per cent ${ }^{47}$.

[Figure 1 about here]

Political experience and information resources are amongst the best predictors of selfidentification as a pollution victim. Having witnessed collective action doubles the probability again to just over seven per cent. The number of books in the house when the respondent was eighteen adds another three per cent.

\footnotetext{
${ }^{47}$ The interpretation of a one standard deviation increase is not straightforward in the case of ordinal and dummy variables, but it is useful as a standard unit because it reflects the fact that differences in variation exist amongst the independent variables. An alternative standard unit would be the change from minimum to maximum values, but this would not capture differences in variation. As in any simulation exercise, these results are intended indicate the substantive significance of the statistical relationships found. They are not equivalent to the probabilistic statements we would derive from the sample without doing any modelling. In fact, the survey shows that one is marginally more likely to be a pollution victim if one lives in an urban rather than a rural area, by a margin of 7 per cent to 5 per cent $(\mathrm{P}<.001)$.
} 
Political attitudes add substantially to these effects. A one standard deviation increase in the seriousness with which global environmental issues are viewed doubles the likelihood of selfidentifying as a pollution victim to 20 per cent. A generalized sense of grievance about unfair treatment adds five per cent. The belief that the poor are poor because of their lack of education adds four per cent. Assigning importance to the local environment as a priority adds another three. The cumulative impact of increasing the values of all significant independent variables by one standard deviation is that the respondent has close to a one in three chance of self-identifying as a pollution victim.

\section{Conclusion}

An important limitation of this article is that it is based on only one cross-sectional survey. Follow-up studies, repeating the environmental module of questions used in 2006 would be required to confirm whether the picture presented here still holds true. Another limitation is that the contextual data on environmental pollution may be insufficiently fine-grained to capture the real impact of pollution on awareness of harm, and hence lead us to overstate the importance of subjective factors. Nevertheless, the article is the first to profile self-identified pollution victims in China and in this way breaks new ground.

Chapter 20 of China's Agenda 21 endorses the goal of increasing public participation in environmental governance ${ }^{48}$. Without involvement by the public, it will be difficult to restructure institutions to serve necessary ecological rationalities such as the circular economy, sustainability and stewardship of resources for future generations ${ }^{49}$. Traditional top-down controls are no longer seen as adequate to enforce even relatively straightforward regulations on the types and quantities of pollutants enterprises can emit ${ }^{50}$. At least part of the Chinese public appears to be ready to take on its new role. Between 1990 and 2006, the annual number of incidents giving rise to complaints to Environmental Protection Bureaux (EPBs) in China increased by 450 per cent from 111,359 to $612,122^{51}$. The increase in complaints reflected institutional adjustments by the Chinese authorities designed to encourage public participation in such forms as letters and visits (xinfang), use of national and local environmental hotlines, participation in EIA public hearings and water price setting, and, as a last resort, civil law suits against polluting enterprises ${ }^{52}$. .

\footnotetext{
${ }^{48}$ Yuhong Zhao, "Public Participation in China's EIA Regime: Rhetoric or Reality?," Journal of Environmental Law 22, no. 1 (2010), p.94

${ }^{49}$ Arthur P. J. Mol, "Environment and Modernity in Transitional China: Frontiers of Ecological Modernization," Development \& Change 37, no. 1 (2006), p.30; Peter Christoff, "Ecological Modernisation, Ecological Modernities," Environmental Politics 5, no. 3 (1996), p.490

${ }^{50}$ van Rooij, "The People Vs. Pollution: Understanding Citizen Action against Pollution in China", p.56

${ }^{51}$ Brettell, "Channelling Dissent: The Institutionalization of Environmental Complaint Resolution", p. 111

${ }^{52}$ Carter and Mol, "China and the Environment: Domestic and Transnational Dynamics of a Future Hegemon", p.337. Brettell, "Channelling Dissent: The Institutionalization of Environmental Complaint Resolution", pp.123-132; Zhang, "Green Bounty Hunters: Engaging Chinese Citizens in Local Environmental Enforcement" p.143f; Zhao, "Public Participation in China's EIA Regime: Rhetoric or Reality?", p.91
} 
However, it may behove us to retain a certain degree of scepticism about the capacity of the public to become the pivot on which China's developmental trajectory will turn. Case studies suggest Chinese pollution victims continue to face formidable institutional barriers to effective action including cost, slowness, lack of impartiality, corruption, legal and scientific complexity, lack of intermediary institutions, and physical distance; whilst the polluting enterprises, often closely connected to the local state, have an armoury of techniques at their disposal including stalling tactics, use of connections, buying off victims and, occasionally, rent-a-mob violence ${ }^{53}$. Moreover, even though there is a trend towards more frequent protests, including boycotts, demonstrations, collective law suits, collective petitions and coordinated internet activity, and some have been successful in achieving their goals ${ }^{54}$, it remains the case that protests are exceptional and successful ones even more so, due to the sharp inequalities in distribution of power which are characteristic of an authoritarian system ${ }^{55}$.

To what extent can we rely on the dynamic between pollution and public response to generate the motivational structure to turn the environmental situation around? The China General Social Survey of 2006 asked a series of follow-up questions of those respondents who self-identified as pollution victims ${ }^{56}$. First, CGSS asked whether pollution victims had taken any action on the most severe occasion ${ }^{57}$. Only a quarter had done so. Amongst the types of action taken, contacting the polluter and contacting government departments were the two dominant strategies, each favoured by just over two-fifths of the pollution victims. Of the 169 who took action, 63 per cent were dissatisfied with the result, and the type of action taken seemed to make little difference ${ }^{58}$. Only four per cent of victims said they went to the news media and only one per cent went to court. Engaging in these forums presents difficult challenges. ${ }^{59}$ The 495 respondents who self-identified as pollution victims but did not take any action were asked about their reasons for not doing so.

\footnotetext{
${ }^{53}$ van Rooij, "The People Vs. Pollution: Understanding Citizen Action against Pollution in China", p.58, 65, 67, 74

54 An MEP source put the number of such disputes at 51,000 in 2004 and 128,000 in 2005. See Tianjie Ma,

"Environmental Mass Incidents in Rural China," China Environment Series, no. 10 (2009), p.35. In July 2012, protests in Shifang, Sichuan province, led officials to cancel plans to build one of the world's largest copper smelting plants. Other examples of protests leading to the cancellation, closure or relocation of factories include in 2011 a coal-fired power plant in Haimen, Guangdong province, a solar energy company in Jiaxing, Zhejiang province and a PX plant in Dalian; in 2009 a waste incineration plant in Panyu, Guangdong province; in 2007 a PX plant in Xiamen; and in 2005 chemical plants in Dongyang village, Zhejiang province. A litany of cases, however, does not prove that environmentalists are winning the struggle as there are many more cases where such a positive outcome did not occur, relocation does not necessarily improve the overall environmental effect, and there is often a long delay between announcement of a decision and actual closure. A detailed examination of mass incidents is beyond the scope of this paper, but for analysis see Ma, "Environmental Mass Incidents in Rural China" and Jing, "Environmental Protests in Rural China".

${ }^{55}$ Susan Martens, "Public Participation with Chinese Characteristics: Citizen Consumers in China's Environmental Management," Environmental Politics 15, no. 2 (2006), p.64f

${ }^{56}$ Admittedly, we are on less certain ground here: instead of analysing, as above, a sample with thousands of cases, we are now looking at a subsample of 664 .

${ }^{57}$ The question was: (If suffered harm) In that case, on the occasion when you suffered most from pollution, did you take any action?

${ }^{58} 72$ per cent of those who contacted the polluter were dissatisfied as against 63 per cent who contacted the government and 73 per cent of those who contacted both and 47 per cent of those who did neither.

${ }^{59}$ van Rooij, "The People Vs. Pollution: Understanding Citizen Action against Pollution in China", p.70f, p.72f
} 
The largest group, 43 per cent, said they had thought about it but knew it would be of no use. A smaller group, 11 per cent, said they had thought about it but decided it would be too much trouble, or the price would be too high. Around a fifth (19 per cent) had thought about it, but didn't know what to do. Around the same number (22 per cent) said they hadn't thought about it, as they could put up with the problem, and the remaining few (4 per cent) gave other responses.

If NIMBY protest and remonstrance with official institutions offer little hope of creating a motivational structure for effective action against pollution, what about NGOs? CGSS also asked the full sample of 10,151 about whether they had joined or would consider joining a self-organised (minjian) environmental protection group ${ }^{60}$. Less than one per cent of respondents said they had, but an enormous number, 62 per cent said "Yes, I would like to in future if there is an opportunity," 18 per cent said they would not like to and 19 per cent weren't sure. It is hard to interpret the fact that more than three fifths said they would like to join an NGO, but close analysis of these data suggests that as in the United States, willingness to join depends on a mixture of collective interests (personal and group efficacy combined with the value placed on the environment) and selective incentives (costs and benefits) ${ }^{61}$. This raises the question of whether altruistic, sociotropic or even nationalistic concern for the environment could replace the egocentric sense of victimhood as a motivating force. In theory, it seems possible, and this would give ENGOs a powerful voice. However, the authorities are sensitive to the dangers mass membership NGOs would present to the present regime ${ }^{62}$. With a few exceptions, existing ENGOs are generally unwilling to become involved in pollution disputes for fear of endangering their "embedded" status, which depends on good relations with the local authorities ${ }^{63}$.

Putting China's development path on a sustainable footing requires lowering the people's tolerance level for pollution and increasing their readiness to use voice to protect themselves, their

\footnotetext{
${ }^{60}$ The question was: Would you like to join an NGO engaged in environmental protection activities? Yes, and I have already done so; Yes, I would like to in future if there is an opportunity; No; Don't know.

${ }^{61}$ Neil Munro, "Polite Interest or Passion? Willingness to Join Green NGOs in China," in The 5th International Forum for Contemporary Chinese Studies (IFCCS5): "Contending Models for China's Future Development: Society Building and Governance" (Beijing, 8-9 August 2012).

62 By the end of 2005 there were 2768 registered environmental NGOs in China including only 202 which were selforganised by members of the public according to Zhao, "Public Participation in China's EIA Regime: Rhetoric or Reality?", p.117. Membership size tends to be quite small. For a typology based on case studies, see Lei Xie, Environmental Activism in China (London: Routledge, 2009). For discussions of government regulation of ENGOs see Jonathan Schwartz, "Environmental NGOs in China: Roles and Limits," Pacific Affairs 77, no. 1 (2004), pp.28-49. Peter Ho, "Sprouts of Environmentalism in China? Government-Organized NGOs and Green Organizations in Disguise," in Shades of Green: Environmental Activism around the Globe, ed. C. Mauch, N. Stoltzfus, and D. R. Weiner, pp.135-60 (Lanham and Oxford: Rowan \& Littlefield Publishers, 2006). Shui-Yan Tang and Xueyong Zhan, "Civic Environmental NGOs, Civil Society, and Democratisation in China," Journal of Development Studies 44, no. 3 (2008), pp.425-48.

63 The leading environmental NGO in this area, the Centre for Legal Assistance to Pollution Victims, restricts itself to providing legal advice and is only able to get directly involved in about one per cent of the complaints brought to it. Another NGO called Shouwang Jiayuan trains activists in water pollution disputes but faces pressure from the authorities, which has lead to the arrest of one of the core activists according to van Rooij, "The People Vs. Pollution: Understanding Citizen Action against Pollution in China", p.70, 73
} 
livelihoods and their environment. As Economy ${ }^{64}$ puts it "turning the environmental situation in China around will require something far more difficult than setting targets and spending money; it will require revolutionary bottom-up political and economic reforms." Unfortunately, history shows that to succeed such reforms require their own "inbuilt energy supply" - a motivational structure which makes their implementation seem logical and necessary to the majority of relevant actors pursuing their own interests. In a context where so few people are aware of the harm pollution causes to themselves, and where the regime is unwilling to allow a broader mobilization by civil society groups around environmental issues, it is difficult to see how such a motivational structure can come into being.

${ }^{64}$ Elizabeth C. Economy, "The Great Leap Backward? The Costs of China's Environmental Crisis," 86(2007), p.39 
Table 1. Self-Identification as a Pollution Victim in China

QE40.In the past year, have you or members of your family suffered harm, either healthrelated or of an economic nature, due to environmental pollution (including air pollution, water pollution, solid waste, noise etc.)?

Yes

$\%$

6

$\mathrm{N}$

No

94

664

9,847

Source: China General Social Survey (CGSS), fieldwork 10 September to 29 November 2006, $\mathrm{N}=10,151$. 
Table 2. Hierarchical Model of Self-Identification as a Pollution Victim

\begin{tabular}{lrrrr}
\hline \multicolumn{1}{c}{ City-level indicators } & Coefficient & S.E. & T-ratio & P-value \\
Industrial waste water per capita, tonnes & -4.37 & .22 & -19.44 & .000 \\
Population of city with jurisdiction, millions & .010 & .004 & 2.64 & .009 \\
GDP per capita, thousand yuan & .04 & .01 & 2.60 & .010 \\
$\quad$ Neighbourhood types & .002 & .005 & .44 & .659 \\
Rural plain & & & & \\
Industrial enterprise danwei & 1.34 & .29 & 4.68 & .000 \\
Mountain or plateau & 1.08 & .27 & 4.00 & .000 \\
Recently developed rural land & 1.01 & .32 & 3.20 & .002 \\
Affordable housing (jingji shiyong fang) & 1.05 & .38 & 2.77 & .006 \\
Unreconstructed old city, shanty & .66 & .30 & 2.19 & .028 \\
Ordinary commercial housing & .62 & .27 & 2.33 & .020 \\
Professional danwei, high-end & & 0 Omitted & & \\
$\quad$ Individual characteristics & .44 & .38 & 1.17 & .242 \\
Has witnessed collective action & & & & \\
Experience of unfair treatment & 1.22 & .15 & 8.18 & .000 \\
Books in house at 18 & .69 & .10 & 7.15 & .000 \\
Reads periodicals, newspapers & .13 & .05 & 2.75 & .006 \\
Global environmental problems serious & .05 & .03 & 1.39 & .164 \\
Poor are poor because lack education & .53 & .09 & 5.86 & .000 \\
Local environment an important priority & .24 & .08 & 3.08 & .002 \\
Rich vs. poor conflicts are serious & .11 & .05 & 2.25 & .025 \\
Trusts government information & .12 & .07 & 1.81 & .071 \\
& -.11 & .06 & -1.75 & .079
\end{tabular}

Chi-squared Tests of Alternative Models

Model
A. No city-level predictors
B. Add waste water per capita
C. Add population of city
D. Add GDP per capita

A-D Reject $A$

B-D Reject B

C-D Consider C

Variance
Intercept
.88
.87
.83
.83
.05
.04
.00

Chi-

square

890.56

881.28

854.08

853.81

36.75

27.47

(5\%)

$0 \%$

.27
DF

737

736

735

734

3

2

1
P

.000

.000

.002

.002

.000

.000

.671

Note: Variance of intercept=Variance of logged odds that respondent was aware of environmental harm when all predictors have zero effects; Chi-square=test statistic for hypothesis that variance of intercept $=0 ; D F=$ degrees of freedom; $P=$ Probability that the Chi-square is due to chance (reject if $P<.15$ )

Source: China General Social Survey (CGSS), fieldwork 10 September to 29 November 2006, Sub-sample under jurisdiction of cities at prefecture level and above, $N=7,550$ 
Figure 1. Impacts on the probability of self-identification as a pollution victim

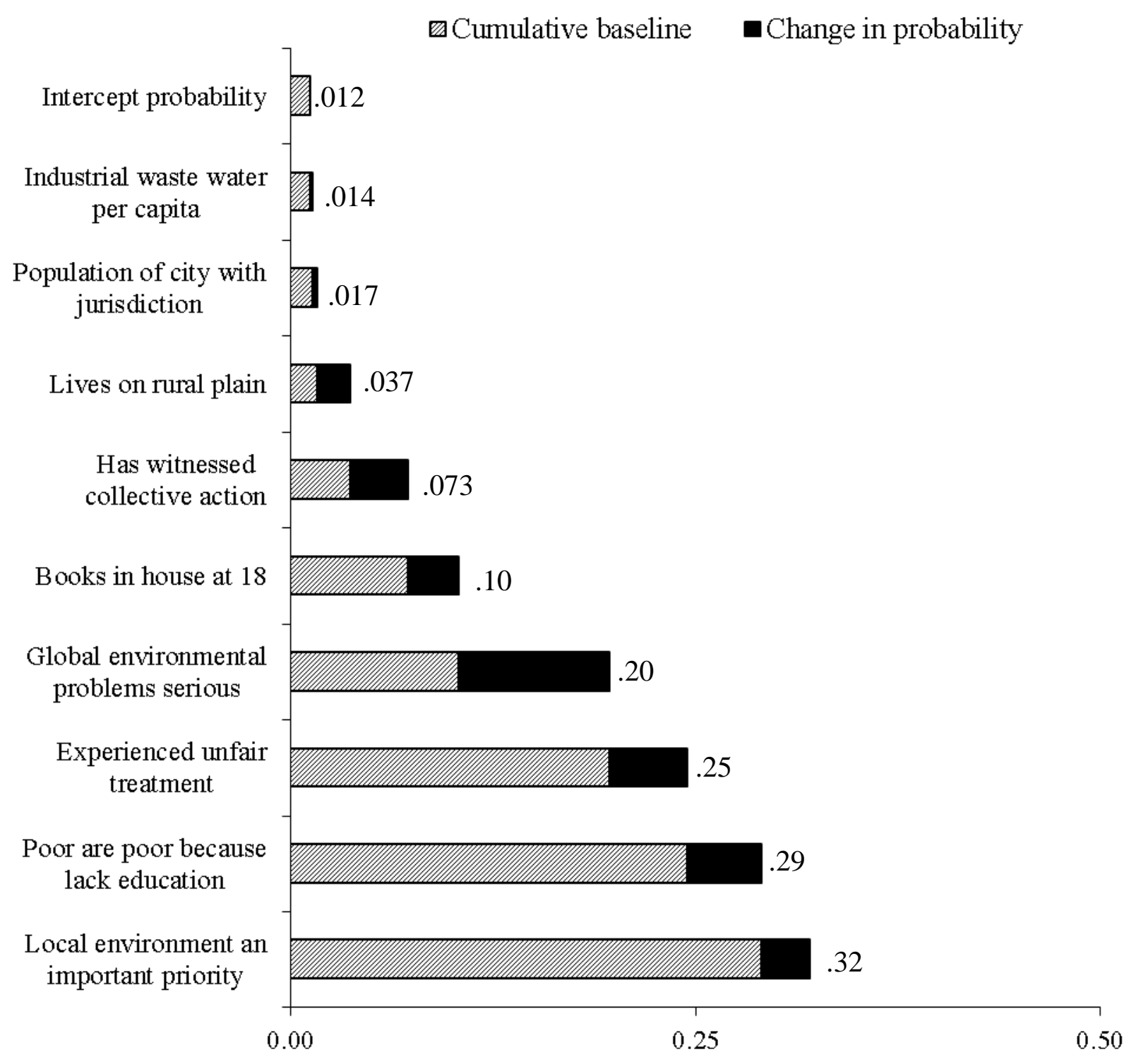

Probability of self-identifying as a victim

Source: Hierarchical model of awareness of environmental harm: areas under the jurisdiction of cities at prefecture-level and above (Table 2). Change in Probability shows the impact on the probability of identifying oneself as a pollution victim of a one standard deviation change in the value of the independent variables significant at .05 level. 
Appendix. Variables Tested in Multivariate Models

\begin{tabular}{|c|c|c|c|c|c|c|}
\hline & & & Full & sample & Tab & \\
\hline Dependent Variable & Min. & Max. & Mean & Stdev & Mean & Stdev \\
\hline Self-identifies as pollution victim & 0 no & 1 yes & .06 & .23 & .05 & .22 \\
\hline City-level environmental indica & tors & & & & & \\
\hline Industrial waste water per capita & 1.77 tonnes & 112.08 tonnes & $\mathrm{Na}$ & & 20.59 & 18.37 \\
\hline Population of city & .84 million & 32.35 million & $\mathrm{Na}$ & & 6.26 & 4.29 \\
\hline GDP per capita, thousand yuan & 5.89 & 84.10 & $\mathrm{Na}$ & & 30.20 & 21.26 \\
\hline Density of $\mathrm{SO}_{2}$, tonnes/sq. $\mathrm{km}$ & .26 & 57.48 & $\mathrm{Na}$ & & 11.62 & 13.35 \\
\hline $\begin{array}{l}\text { Airborne dust, tonnes/sq. km } \\
\text { Neighbourhood types }\end{array}$ & 17 & 13.56 & $\mathrm{Na}$ & & 2.93 & 2.75 \\
\hline Rural plain & 0 No & 1 Yes & 19 & .40 & 23 & .42 \\
\hline Affordable housing & 0 No & 1 Yes & .08 & .27 & .09 & .28 \\
\hline Moun & 0 No & 1 Yes & .22 & .41 & .22 & .41 \\
\hline Indus & 0 No & 1 & .12 & .32 & .11 & .31 \\
\hline old city, shanty & 0 No & 1 Yes & .14 & .35 & .13 & .33 \\
\hline lanwei, high-end & 0 No & 1 Yes & .06 & .23 & .05 & .23 \\
\hline Recel & 0 No & es & .04 & .19 & .02 & .16 \\
\hline $\begin{array}{l}\text { Ordinary commercial housing } \\
\text { Individual characteristics }\end{array}$ & 0 No & 1 Yes & .16 & .36 & .14 & .35 \\
\hline Has witnessed collective action ${ }^{1}$ & 0 No & 1 Yes & .10 & .31 & .09 & .29 \\
\hline ffair tre & 0 Never & 2 Twice+ & .14 & .44 & .13 & .42 \\
\hline Books & $1 \mathrm{No}$ & $0+$ & 2.05 & 1.26 & 2.09 & 1.27 \\
\hline Reads peric & $1 \mathrm{Nev}$ & 7 Daily & 3.95 & 2.51 & 4.04 & 2.52 \\
\hline $\begin{array}{l}\text { Global environmental problems } \\
\text { serious }\end{array}$ & 1 Not at all & 5 Very serious & 3.75 & .81 & 3.75 & .82 \\
\hline $\begin{array}{l}\text { Poor are poor because they lack } \\
\text { education }\end{array}$ & $\begin{array}{l}1 \text { Totally } \\
\text { disagree }\end{array}$ & 4 Totally agree & 2.75 & .80 & 2.73 & .81 \\
\hline $\begin{array}{l}\text { Local environment an important } \\
\text { priority }\end{array}$ & 0 Not at all & $\begin{array}{l}3 \text { Very } \\
\text { important }\end{array}$ & .69 & 1.12 & .68 & 1.12 \\
\hline Rich vs. poor conflicts serious & $1 \mathrm{No}$ & 4 Very & 2.64 & .90 & 2.65 & .91 \\
\hline $\begin{array}{l}\text { Trusts government information } \\
\text { Social structural characteristics }\end{array}$ & $1 \mathrm{Lea}$ & 5 Most & 3.87 & .86 & 3.86 & .87 \\
\hline Gender & $0 \mathrm{Me}$ & & .54 & .50 & .54 & .50 \\
\hline Educe & 1 Primary- & 4 University & 2.14 & 1.00 & 2.17 & 1.01 \\
\hline Age: & 0 No & $1 \mathrm{Y}$ & .20 & .40 & .20 & .40 \\
\hline Age: 3 & 0 No & 1 Yes & .24 & .42 & .22 & .42 \\
\hline Age: $40 \mathrm{~s}$ & 0 No & 1 Yes & .24 & .42 & .24 & .43 \\
\hline Age: 5 & 0 No & 1 Yes & .20 & .40 & .21 & .41 \\
\hline Age: 6 & 0 No & 1 Yes & .13 & .34 & .13 & .34 \\
\hline 000 RMB & 0 None & 10 & 21.14 & 19.24 & 21.72 & 20.02 \\
\hline Resic & 0 No & 1 Yes & .49 & .50 & .51 & .50 \\
\hline Residence permit: full urban & 0 No & 1 Yes & .48 & .50 & .46 & .50 \\
\hline
\end{tabular}

Source: CGSS data in Tables 2-5. Contextual variables from National Bureau of Statistics. 2008 China City Statistical Yearbook. Beijing: China Statistics Press, 2008, Table 2-42

1. Including collective boycotts of unreasonable fees, collective resistance to land requisitioning or relocation, collective participation in environmental protection activities, collective gathering of signatures, negotiating, appeals, petitions, lawsuits, meetings, marches, demonstrations etc. 2. Unfairness in nine categories: property disputes, land requisition, urban sprawl, enterprise restructuring, losing a job, distribution of land for housing, grassroots elections, allocation of work responsibilities, other. 